\title{
Inorganic carbon time series at Ocean Weather Station $M$ in the Norwegian Sea
}

\author{
I. Skjelvan ${ }^{1,2}$, E. Falck ${ }^{2}$, F. Rey ${ }^{3}$, and S. B. Kringstad ${ }^{2,1}$ \\ ${ }^{1}$ Bjerknes Centre for Climate Research, University of Bergen, Norway \\ ${ }^{2}$ Geophysical Institute, University of Bergen, Norway \\ ${ }^{3}$ Institute of Marine Research, Bergen, Norway
}

Received: 15 August 2007 - Published in Biogeosciences Discuss.: 27 August 2007

Revised: 18 February 2008 - Accepted: 18 March 2008 - Published: 10 April 2008

\begin{abstract}
Dissolved inorganic carbon $\left(C_{T}\right)$ has been collected at Ocean Weather Station M (OWSM) in the Norwegian Sea since 2001. Seasonal variations in $C_{T}$ are confined to the upper $50 \mathrm{~m}$, where the biology is active, and below this layer no clear seasonal signal is seen. From winter to summer the surface $C_{T}$ concentration typical drop from 2140 to about $2040 \mu \mathrm{mol} \mathrm{kg}{ }^{-1}$, while a deep water $C_{T}$ concentration of about $2163 \mu \mathrm{mol} \mathrm{kg}{ }^{-1}$ is measured throughout the year. Observations show an annual increase in salinity normalized carbon concentration $\left(n C_{T}\right)$ of $1.3 \pm 0.7 \mu \mathrm{mol} \mathrm{kg}^{-1} \mathrm{yr}^{-1}$ in the surface layer, which is equivalent to a $p \mathrm{CO}_{2}$ increase of $2.6 \pm 1.2 \mu \mathrm{atm} \mathrm{yr}^{-1}$, i.e. larger than the atmospheric increase in this area $\left(2.1 \pm 0.2 \mu \mathrm{atm} \mathrm{yr}^{-1}\right)$. Observations also show an annual increase in the deep water $n C_{T}$ of $0.57 \pm 0.24 \mu \mathrm{mol}$ $\mathrm{kg}^{-1} \mathrm{yr}^{-1}$, of which about $15 \%$ is due to inflow of old Arctic water with larger amounts of remineralised matter. The remaining part has an anthropogenic origin and sources for this might be Greenland Sea surface water, Iceland Sea surface water, and/or recirculated Atlantic Water. By using an extended multi linear regression method (eMLR) it is verified that anthropogenic carbon has entered the whole water column at OWSM.
\end{abstract}

\section{Introduction}

The ocean is one of several reservoirs indirectly controlling the climate system through exchange of $\mathrm{CO}_{2}$ with the atmosphere. Human activities, such as burning of fossil fuels and deforestation, release annually an anthropogenic carbon amount of about $7.2 \times 10^{15} \mathrm{~g} \mathrm{C}$ into the atmosphere, and of this, about one third is taken up by the world oceans (Solomon et al., 2007). The North Atlantic is known to store relatively large amounts of anthropogenic carbon, which has

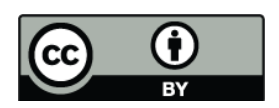

Correspondence to: I. Skjelvan (ingunn.skjelvan@gfi.uib.no) been captured through formation of intermediate and deep waters in subpolar areas (e.g. Álvarez et al. 2003; Friis et al., 2005; Olsen et al., 2006). It is, however, not straightforward to quantify this amount, due to a lack of oceanic reference data from the pre-industrial times, and alternative methods have to be used, such as back-calculation techniques (e.g. Brewer, 1978; Chen and Millero, 1979; Gruber et al., 1996) or empirical methods (Wallace, 1995; Goyet et al., 1999; Friis et al., 2005).

The Nordic Seas in the North Atlantic are an important sink for atmospheric $\mathrm{CO}_{2}$ (e.g. Takahashi et al., 2002; Skjelvan et al., 2005). Takahashi et al. (2002) pointed out that the size of the sink is increasing due to an unchanged surface ocean $p \mathrm{CO}_{2}$ signal in this area over the years. Recent research suggests, on the contrary, that the size of the Nordic Seas sink seems to be regionally decreasing, based on an observed seawater $p \mathrm{CO}_{2}$ which annually increases faster than the atmospheric $p \mathrm{CO}_{2}$ (Olsen et al., 2006). Carbon time series data from this area are, in this respect, valuable contributions to evaluate the development of the oceanic carbon uptake.

The Ocean Weather Station M (OWSM) is situated in the western branch of the Norwegian Atlantic Current, at $66^{\circ} \mathrm{N}$; $2^{\circ} \mathrm{E}$, over the Norwegian continental slope (Fig. 1). The station, which has a depth of about $2100 \mathrm{~m}$, was started in 1948 and is today operated by M/S Polarfront; the last weather ship in the world. Temperature and salinity have been measured from the very beginning (e.g. Østerhus and Gammelsrød, 1999; Nilsen and Falck, 2006), closely followed by dissolved oxygen (Nilsen and Falck, 2006; Kivimäe and Falck, $2007^{1}$ ). In the 1980s analyses of atmospheric $\mathrm{CO}_{2}$ content were started (Tans and Conway, 2005), and since 1990 nutrients have been determined weekly (Dale et al., 1999). During a four years period and on a monthly basis in the early $1990 \mathrm{~s}$, total dissolved inorganic carbon $\left(C_{T}\right)$ was

\footnotetext{
${ }^{1}$ Kivimäe, $\mathrm{C}$ and Falck, E.: Interannual variability of net community production at Ocean Weather Station M in the Norwegian Sea during 51 years, Global Biogeochem. Cy., submitted 2007.
}

Published by Copernicus Publications on behalf of the European Geosciences Union. 


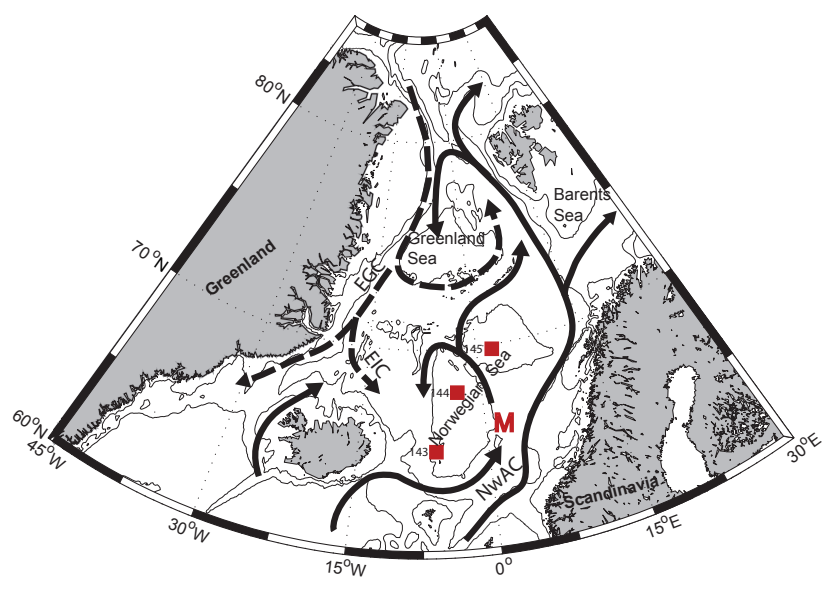

Fig. 1. Schematic of the northern North Atlantic Ocean. The solid lines indicate the flow of warm Atlantic Water and the dashed lines show the flow of cold Polar and Arctic Water. NwAC is the Norwegian Atlantic Current, EGC is the East Greenland Current, and EIC is the East Icelandic Current. M denotes Ocean Weather Station M (OWSM) and the red squares indicate TTO stations used for estimating anthropogenic carbon increase at OWSM.

determined for the very first time at OWSM, using gas extraction of acidified water samples and manometric detection (Gislefoss et al., 1998), however, these are not used in the following due to insufficient precision $\left( \pm 12 \mu \mathrm{mol} \mathrm{kg}^{-1}\right)$. Since November 2001 monthly measurements of $C_{T}$ have been performed using modern analyzing techniques.

Warm and saline Atlantic Water from the Norwegian Atlantic Current occupies the upper layer at OWSM down to $300-400 \mathrm{~m}$, with present temperatures typically varying between $7^{\circ} \mathrm{C}$ in the winter and $12^{\circ} \mathrm{C}$ in the summer time (Fig. 2a). Cold and less saline deep water occupies the water column from about $1000 \mathrm{~m}$ down to the bottom (Norwegian Sea Deep Water), and in between these two water masses there is a layer of intermediate water; Arctic Intermediate Water, of fluctuating thickness. At times with northerly or north-easterly winds during summer, the fresher Norwegian Coastal Water is driven away from the coast and will occasionally reach all the way out to OWSM (Fig. 2b). We refer to Nilsen and Falck (2006) for a more thorough description of the hydrographic conditions in the OWSM area.

In this paper we present the new $C_{T}$ time series data from OWSM in the Norwegian Sea since fall 2001. We describe the seasonal and interannual variations, and we use the multiple linear regression (MLR) method of Wallace (1995) in an extended version (eMLR) formalized by Friis et al. (2005) to determine the anthropogenic $\mathrm{CO}_{2}$ increase in this area of the Nordic Seas during the last two decades since the Transient Tracers in the Ocean, North Atlantic Study (TTO-NAS) expedition in 1981.

\section{Data}

At present, hydrographic measurements at OWSM are performed using a Sea-Bird CTD (SBE 37-SM MicroCAT with conductivity, temperature, and pressure sensors), which is calibrated towards bottle salinity samples. Nansen bottles, with reversing thermometers, are used to collect samples for inorganic carbon, dissolved oxygen, nutrients, and salinity at standard depths. Samples for $C_{T}$ are conserved with $0.02 \%$, by volume, of saturated $\mathrm{HgCl}_{2}$ solution and analysed ashore in general within a month. However, a few samples have been stored for up to six months when the analytical instruments have been occupied at cruises. $C_{T}$ is determined by gas extraction of acidified water samples and further coulometric titration (Johnson et al., 1993; DOE, 1994), and accuracy is set by running CRM supplied by Andrew Dickson of Scripps Institution of Oceanography. The precision (standard deviation) is $\pm 0.5 \mu \mathrm{mol} \mathrm{kg}-1$ based on 10 duplicate samples. Dissolved oxygen is measured on board using the Winkler titration method with visual detection of the titration end point, and this in general gives a precision of $1 \%$. Nutrients are conserved using chloroform and kept at $4^{\circ} \mathrm{C}$ until analysis ashore within six weeks after sampling. The analyses were made using standard methods on a Skalar Auto Analyzer until 2003 and an Alpkem Auto Analyzer since then. Precision for nitrate, phosphate, and silicate are 3\%, 4\%, and $2 \%$, respectively. The salinity samples are analyzed ashore within a month after sampling using PorterSal salinometer with a precision of 0.003 . Due to technical problems there is a gap in the time series from April to October 2004, i.e. no water samples were collected during this period.

The TTO-NAS ran from April to October 1981 and consisted of 7 legs. In the present study we have used data from leg 5, which was carried out during July and August 1981 in the Nordic Seas, and the precision of the inorganic carbon data from this cruise is reported to be $\pm 3.7 \mu \mathrm{mol} \mathrm{kg}{ }^{-1}$. The data were obtained from the Carbon Dioxide Information Analysis Center (Oak Ridge, Tennessee, USA) and are thoroughly described in e.g. Olsen et al. (2006). Tanhua and Wallace (2005) reanalyzed TTO carbon data from legs 2, 3, 4 , and 7, and compared them with modern data adjusted to CRMs. They concluded that the TTO alkalinity data were biased and recommended that these data should be reduced by $3.6 \mu \mathrm{mol} \mathrm{kg}^{-1}$, and that the TTO $C_{T}$ data should be recalculated using adjusted alkalinity data and further increased by $2.4 \mu \mathrm{mol} \mathrm{kg}^{-1}$. No significant leg-specific differences were found for the four legs examined, and based on this the suggested corrections have also been performed on the data from leg 5 .

\section{Seasonal and interannual variability}

The inorganic carbon content of the seawater in this area varies at different time scales. The upper water mass at 

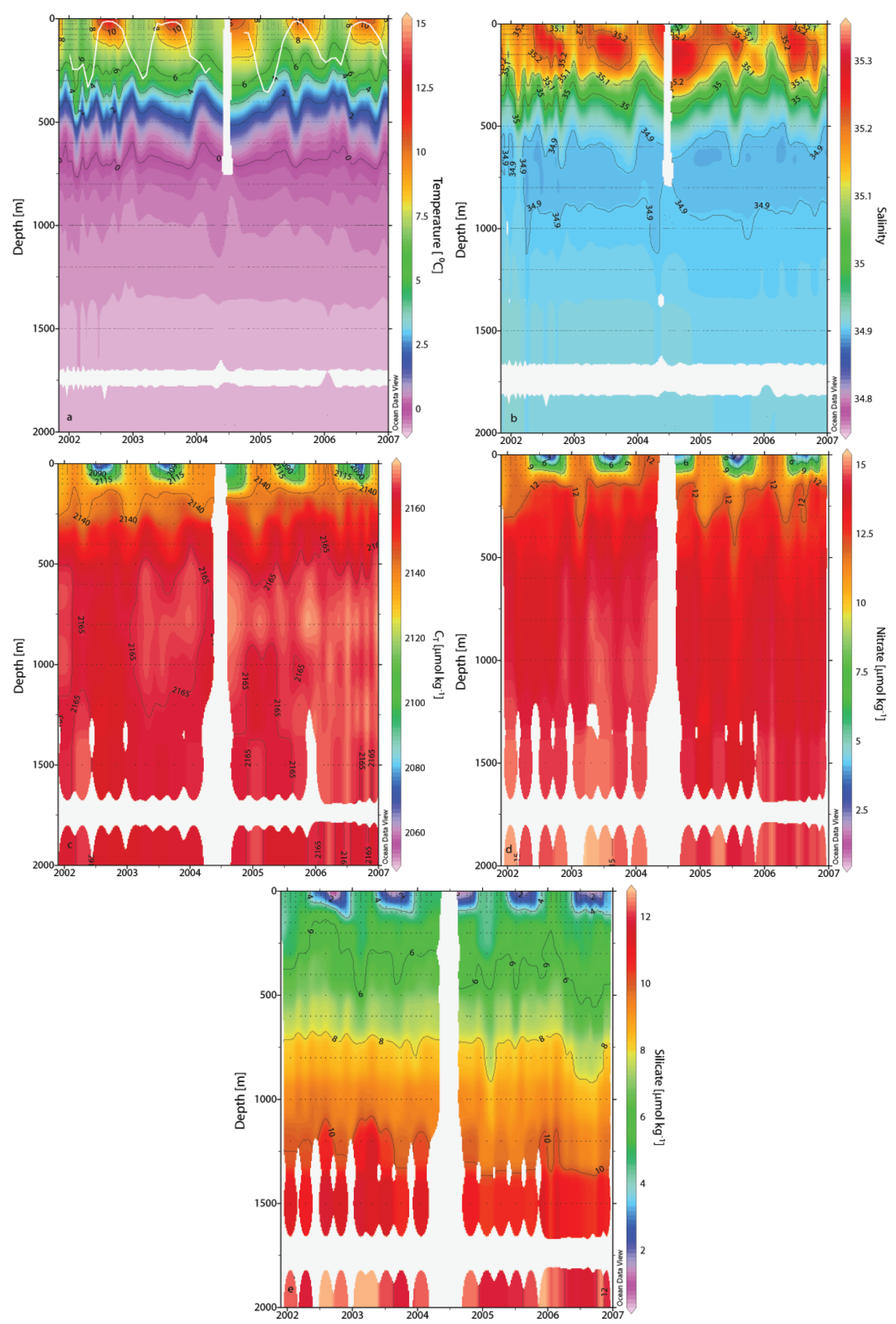

Fig. 2. Hovmöller diagram of water column (a) temperature $\left[{ }^{\circ} \mathrm{C}\right]$ and mixed layer depth (white line), (b) salinity, (c) $C_{T}\left[\mu \mathrm{mol} \mathrm{kg}^{-1}\right]$, (d) nitrate $\left[\mu \mathrm{mol} \mathrm{kg}^{-1}\right]$, and (e) silicate $\left[\mu \mathrm{mol} \mathrm{kg}^{-1}\right]$ during the period 2001 throughout 2006. 

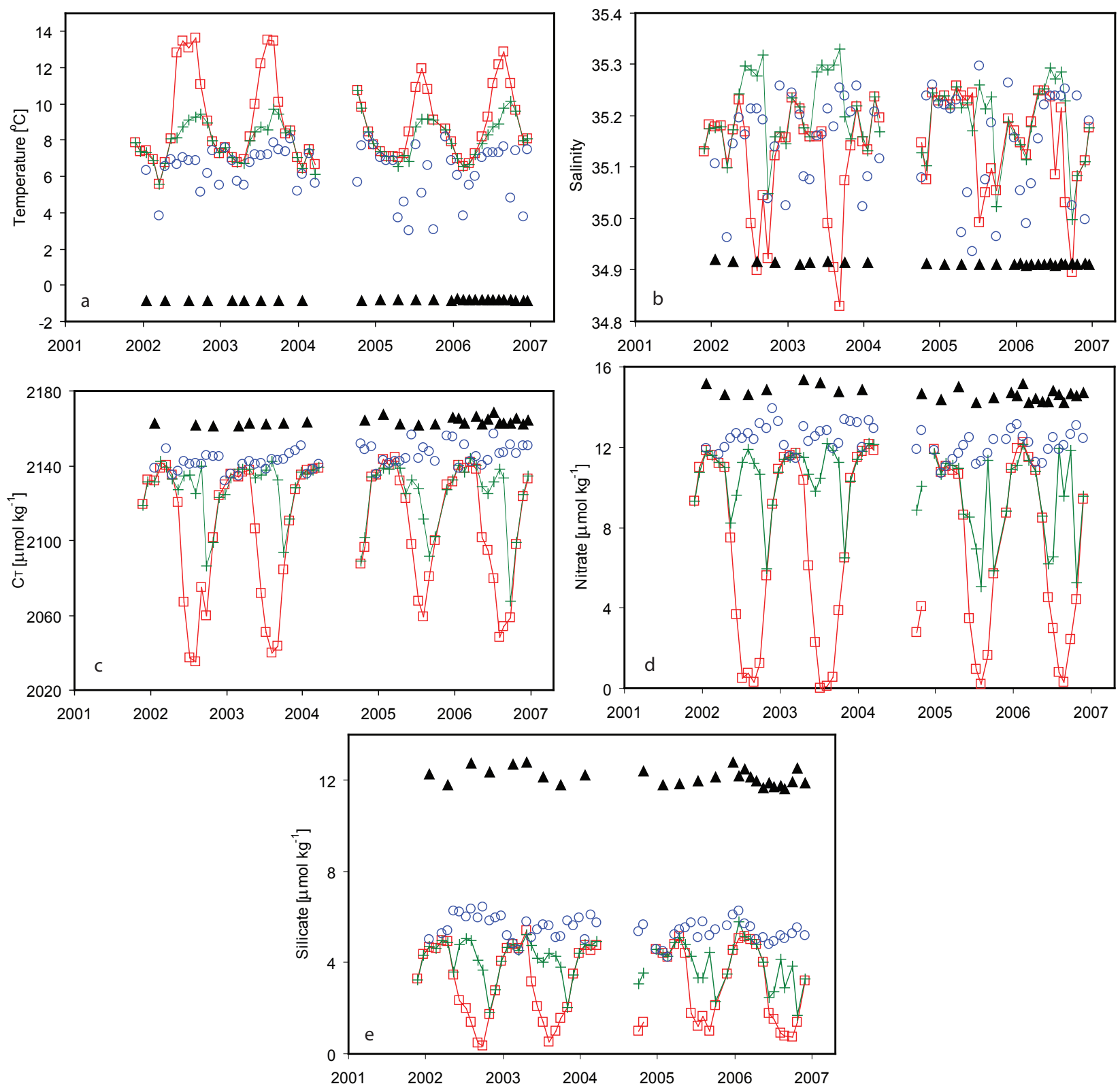

Fig. 3. Seasonal variations in (a) temperature, (b) salinity, (c) $C_{T}$, (d) nitrate, and (e) silicate at different depths as a function of time. Red squares are at $10 \mathrm{~m}$, green crosses are at $50 \mathrm{~m}$, blue circles are at $200 \mathrm{~m}$, and black filled triangles are at $2000 \mathrm{~m}$ depth.

OWSM experiences seasonal changes due to physical, chemical, and biological processes. A clear seasonality is, for instance, seen in the upper layer temperature with warming during the summer seasons and cooling during winters (Fig. 2a). The depth of the mixed layer at OWSM varies in general between $20 \mathrm{~m}$ in summer to $250-350 \mathrm{~m}$ in winter (Fig. 2a) and below the winter mixed layer no clear seasonal signal is seen. For the current work the mixed layer depth (Fig. 2a) was determined as the depth where the $\sigma_{t}$ had changed equivalent to a decrease in the surface temperature of $0.8^{\circ} \mathrm{C}$ (Kara et al., 2000). For density profiles with surface instability stronger than $0.02 \mathrm{~kg} \mathrm{~m}^{-3}$, the first stable value below the surface was used as the surface value.

The depth of the transition layer between the Atlantic Water and the intermediate water at OWSM is known to fluctuate considerably (e.g. Mosby, 1962) and this can clearly be seen in Fig. 2a at depths between 300 and $600 \mathrm{~m}$, where the period of the temperature fluctuations is disconnected with the season. Below about $700 \mathrm{~m}$ the temperature decreases toward the bottom from 0 to about $-0.83^{\circ} \mathrm{C}$.

Panel 2c, d, and e show all the $C_{T}$, nitrate, and silicate data from 2001 to 2006, and in Fig. 3 the temperature, salinity, 
$C_{T}$, nitrate, and silicate are extracted at four depths. The highest variability for all parameters is seen in the surface layer, and this is closely linked to the biological activity starting in the spring and extending into the summer season. Phytoplankton growth starts in April-May as a combined result of increased solar radiation, shallowing of the mixed layer, and the establishment of a seasonal pycnocline (Rey, 2004). With the onset of primary production the concentrations of $C_{T}$ and nutrients decrease in the surface layer. This depletion continues until mid or late summer, when respiration and remineralisation take over as dominating processes controlling the $C_{T}$ and nutrients concentrations.

At $50 \mathrm{~m}$ depth there is a temporary decrease in $C_{T}$, nitrate, and silicate concentrations just after the onset of primary production, when the mixed layer is still deeper than $50 \mathrm{~m}$. The major depletion at this depth appears to occur in September-October (Fig. 3c, d, and e), when the surface water low in $C_{T}$ and nutrients is mixed downwards due to wind mixing and vertical convection achieved by cooling of the surface (Fig. 3a). As the mixed layer depth increases further the carbon and nutrient rich waters from depths below 50 $\mathrm{m}$ are mixed upwards in the water column and reintroduced into the surface layer, increasing the surface concentrations towards winter values.

The biological drawdown during spring and summer is confined to the upper $50 \mathrm{~m}$ and below $100 \mathrm{~m}$ there is no clear seasonal signal in $C_{T}$ and nutrients. From winter to summer the surface $C_{T}$, nitrate, and silicate decrease by about 100 , 11 , and $4 \mu \mathrm{mol} \mathrm{kg}{ }^{-1}$, respectively (Fig. 3c, d, and e). The lowest surface $C_{T}$ concentrations are found in August, while the nutrients have their lowest concentrations in July.

While there is an indisputable difference between summer and winter values in upper waters, no clear seasonal signal is seen in the deeper layers. In the transition zone between the Atlantic Water and the Arctic Intermediate Water (300$600 \mathrm{~m}$; Fig. 2c) the $C_{T}$ concentration increases from about 2140 to about $2165 \mu \mathrm{mol} \mathrm{kg}-1$. In the core of the intermediate water, between about 500 and $1000 \mathrm{~m}$, there is a small $C_{T}$ maximum, and below this the concentration is slightly decreasing towards the bottom. For nitrate (Fig. 2d), the increase in the transition layer is about $2 \mu \mathrm{mol} \mathrm{kg}-1$, with a small further increase of $1 \mu \mathrm{mol} \mathrm{kg}-1$ in the deep water. The silicate concentration (Fig. 2e) increases from about 6 to about $8 \mu \mathrm{mol} \mathrm{kg} \mathrm{kg}^{-1}$ in the transition zone, and increases further towards the bottom. At $2000 \mathrm{~m}$ depth $C_{T}$, nitrate, and silicate values are about 2163,15 , and $12 \mu \mathrm{mol} \mathrm{kg} \mathrm{kg}^{-1}$, respectively, throughout the year. Typical values for the different parameters at different depth layers and seasons are presented in Table 1, however, deviations from these are certainly observed.

When it comes to interannual variations, the degree of inorganic carbon depletion in the mixed layer during summer seasons do vary from year to year; a feature which is also seen in the silicate, but not in the nitrate (Fig. 3c, d, and e). In 2005, the concentration of $C_{T}$ dropped by about
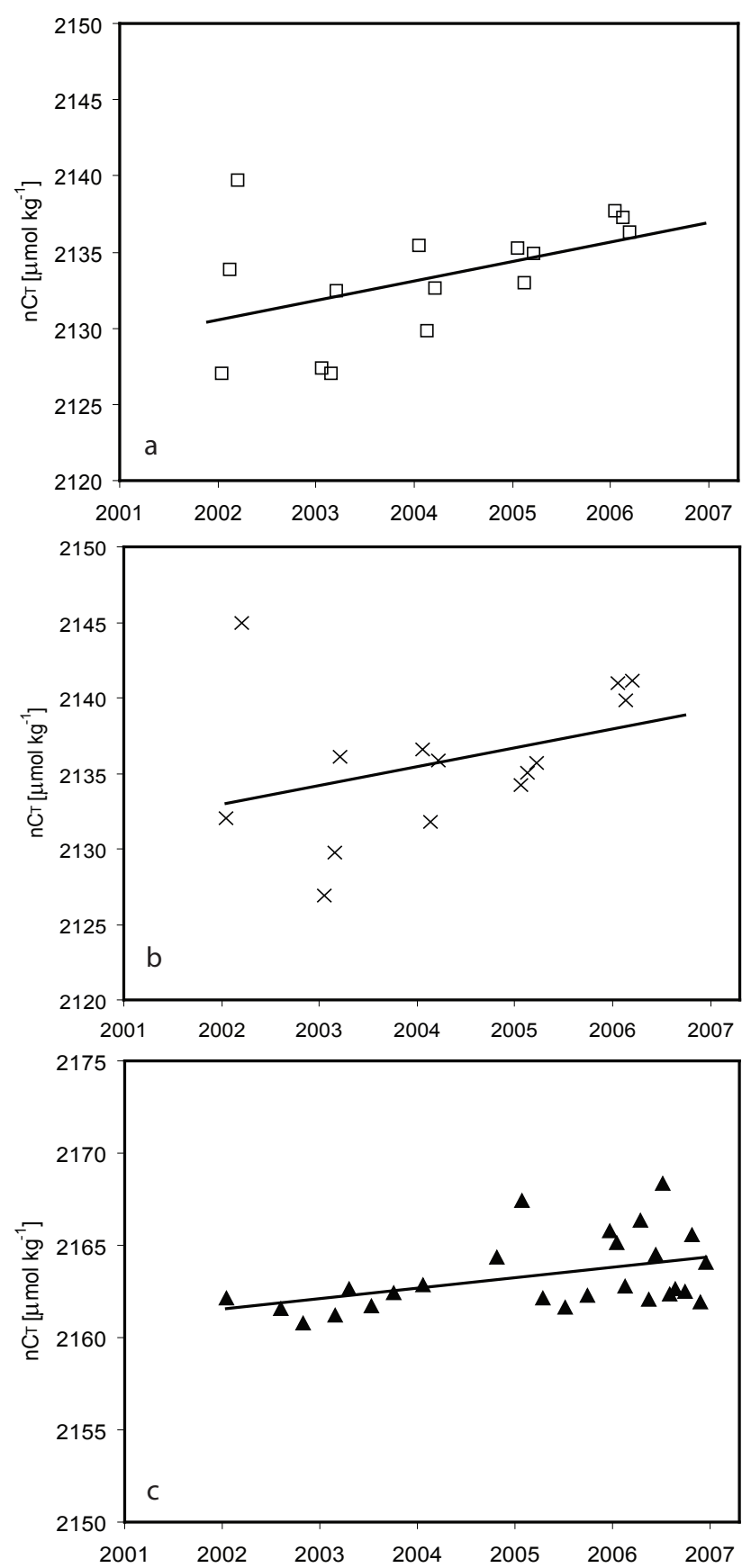

Fig. 4. Salinity normalized carbon concentration over the period 2002-2006 in (a) the surface water during the winter months January to March, (b) the mixed layer during the winter months January to March, and (c) the deep water (four times a year in 20022004, and once a month from 2005 and onwards). The surface $C_{T}$ samples are normalized to a salinity of 35.1 , while the deep water samples are normalized to a salinity of 34.91. Equations, number of data points, $R^{2}$, and significance level for the different regression lines are for (a) $y=1.28 \cdot x-431,15,0.22$, and $92 \%$; for (b) $y=1.25 \cdot x-$ $361,14,0.13$, and $80 \%$; and for (c) $y=0.57 \cdot x+1026,26,0.19$, and $98 \%$. 
Table 1. Mean values of $C_{T}$, nitrate, silicate, temperature, and salinity at OWSM.

\begin{tabular}{llllll}
\hline & $C_{T}\left[\mu \mathrm{mol} \mathrm{kg}^{-1}\right]$ & Nitrate $\left[\mu \mathrm{mol} \mathrm{kg}^{-1}\right]$ & Silicate $\left[\mu \mathrm{mol} \mathrm{kg}^{-1}\right]$ & Temperature $\left[{ }^{\circ} \mathrm{C}\right]$ & Salinity \\
\hline Surface winter & 2140 & 11.5 & 5 & 7 & 35.2 \\
Surface summer & 2040 & $\sim 0$ & $0.5-1$ & 12 & $34.6-35.1$ \\
Deep water & 2163 & 15 & 12 & -0.83 & 34.91 \\
\hline
\end{tabular}

$80 \mu \mathrm{mol} \mathrm{kg}{ }^{-1}$ from winter to summer compared to a $C_{T}$ drop of about $100 \mu \mathrm{mol} \mathrm{kg}^{-1}$ from winter to summer in previous years. A similar picture is seen for the salinity normalized $C_{T}\left(n C_{T}=C_{T} \cdot \mathrm{S} / 35.1\right.$; not shown $)$, which indicates that this feature is not caused by a change in salinity. The feature is mainly explained by a colder surface temperature during summer 2005 compared to the previous summers (see Figs. 2a and 3a). During 2005 the surface temperature was about $2^{\circ} \mathrm{C}$ colder than previous years, and this corresponds to a $C_{T}$ increase of about $16 \mu \mathrm{mol} \mathrm{kg} \mathrm{kg}^{-1}$ (Lewis and Wallace, 1998). Also surface silicate values were less depleted during summer 2005 and 2006 compared to previous summers. The reason for this might be connected to sub-optimal diatom growth or to heavy grazing on diatoms resulting in a lower phytoplankton biomass (Rey, 2004).

To determine the interannual trend in the inorganic carbon content of surface water, the winter surface $(10 \mathrm{~m}) n C_{T}$ concentration during the years 2002 to 2006 is plotted in Fig. 4a. Winter is defined as the months January to March, and a regression line is drawn through the points. The figure shows two things; first, within the same winter the mixed layer in general increases from January towards March, which increases the inorganic carbon concentration in the surface layer. Second, and most interesting when it comes to variations from year to year, the slope of the regression line indicates an annual $n C_{T}$ increase of $1.3 \pm 0.7 \mu \mathrm{mol} \mathrm{kg}^{-1} \mathrm{yr}^{-1}$ (with a significance level of $92 \%$ ). An annual increase of not salinity normalized $C_{T}$ values of $1.5 \pm 0.5 \mu \mathrm{mol} \mathrm{kg}^{-1} \mathrm{yr}^{-1}$ was also determined (not shown), which indicates that less than a tenth of the observed annual increase in surface $C_{T}$ is due to salinity changes. The slope is equivalent to a $p \mathrm{CO}_{2}$ increase of $2.6 \pm 1.2 \mu \mathrm{atm} \mathrm{yr}^{-1}$ assuming a constant alkalinity of $2320 \mu \mathrm{mol} \mathrm{kg}^{-1}$ (Lewis and Wallace, 1998). The winter season was chosen to eliminate any interannual variations due to change in primary production.

The robustness of the interannual signal was investigated by examining the inorganic carbon content in the winter (January to March) mixed layer over the years, since the winter is the time of the year when the mixed layer is deepest and coldest (Nilsen and Falck, 2006). Further, the salinity normalized $C_{T}$ content during the winter months were calculated by integrating $n C_{T}$ throughout the mixed layer (Fig. 4b). The slope of the regression line indicates an increase in the mixed layer $n C_{T}$ content of $1.2 \pm 0.9 \mu \mathrm{mol} \mathrm{kg}^{-1} \mathrm{yr}^{-1}$, equivalent to an annual $p \mathrm{CO}_{2}$ increase of $2.4 \pm 1.6 \mu \mathrm{atm} \mathrm{yr}^{-1}$ if one assumes a constant alkalinity of $2320 \mu \mathrm{mol} \mathrm{kg} \mathrm{kg}^{-1}$ (Lewis and Wallace, 1998); i.e. lower than the increase in oceanic $p \mathrm{CO}_{2}$. According to Tans and Conway (2005) and T. Conway (personal communication) the annual atmospheric $\mathrm{CO}_{2}$ increase at OWSM was $2.1 \pm 0.2 \mu \mathrm{atm} \mathrm{yr}^{-1}$ for the period between 2001 and 2005, and $1.63 \pm 0.03 \mu \mathrm{atm} \mathrm{yr}^{-1}$ for the period between 1982 to 2005 ; i.e. less compared to the oceanic $p \mathrm{CO}_{2}$ increase.

At intermediate depths of 800,1000 , and $1500 \mathrm{~m}$ we observe annual increases in $n C_{T}$ of $1.4,0.8$ and $0.9 \mu \mathrm{mol}$ $\mathrm{kg}^{-1} \mathrm{yr}^{-1}$, respectively. Further, the water at $2000 \mathrm{~m}$ depth (Fig. 4c) also shows an interannual $C_{T}$ signal, and here the $n C_{T}$ is observed to increase by $0.57 \pm 0.24 \mu \mathrm{mol} \mathrm{kg} \mathrm{kg}^{-1} \mathrm{yr}^{-1}$ (significance level of 97\%). This might be connected to the changes seen in the deep water at OWSM during the last decades (Østerhus and Gammelsrød, 1999) and will be discussed further in Chapter 5 .

\section{Determining changes in anthropogenic carbon}

During the last decades there have been numerous attempts to determine the anthropogenic part of the inorganic carbon exchange between the atmosphere and the ocean (e.g. Brewer, 1978; Wallace, 1995; Gruber et al., 1996; Sabine et al., 1999). In this work we have used the extended multi linear regression (eMLR) method documented in Friis et al. (2005) and based on the multivariate time-series method used in Wallace (1995) and Brewer et al. (1995), to determine changes in the anthropogenic carbon content of the water.

This method is based on the assumptions that the spatial $C_{T}$ distribution in a given region can be described by a linear multi-parameter model and that, over the time period of the study, there are no temporal changes in the correlation between $C_{T}$ and the independent parameters used in the method. In the real world, $C_{T}$ is perturbed both by natural variability and anthropogenic input, but it is assumed that when predictive parameters such as salinity, nutrients, $A O U$ (apparent oxygen utilization), or alkalinity are taken into account this can adjust for the natural variations.

The rationale is to use a recent data set from one region; in this case OWSM data from 2005, and compare it with a historical data set from the same region; i.e. data from the TTO-NAS expedition in 1981. $C_{T}$ values from the two time periods are predicted using a combination of independent 
parameters; salinity, nitrate, silicate, and potential temperature, from the respective time periods:

$\mathrm{C}_{T, \text { pred }}^{t}=a^{t}+b^{t} S^{t}+c^{t} \mathrm{NO}_{3}{ }^{t}+d^{t} \mathrm{SiO}_{2}{ }^{t}+e^{t} \theta^{t}$

where $a, b, c, d$, and $e$ are regression coefficients specific for the particular dataset, and $t$ refers to the TTO or OWSM data. The change of anthropogenic carbon in the water column over the time span is then determined by subtracting the time specific equations from each other:

$$
\begin{aligned}
& \Delta \mathrm{C}_{T}^{\mathrm{ant}}=\left(a^{t 2}-a^{t 1}\right)+\left(b^{t 2}-b^{t 1}\right) S^{t 2}+\left(c^{t 2}-c^{t 1}\right) \\
& \mathrm{NO}_{3}^{t 2}+\left(d^{t 2}-d^{t 1}\right) \mathrm{SiO}_{2}^{t 2}+\left(e^{t 2}-e^{t 1}\right) \theta^{t 2}
\end{aligned}
$$

where $t 1$ and $t 2$ represents the TTO and OWSM data, respectively. An advantage of the eMLR approach compared to the MLR is that the measurement error of the independent parameters is minimized since this error is included in the prediction both in the recent and the historical dataset (Friis et al., 2005).

With the view of the Norwegian Sea as a diatom dominated area, it makes sense that silicate is one of the parameters that should be included in the predictive term for $C_{T}$. On the other hand, parameters like phosphate and $A O U$ were also considered in the regression, with not as good fit as with the present combination of parameters. The use of phosphate and $A O U$ even resulted in $C_{T}$ residuals with a biased variation with depth, which indicates that these parameters are not independent.

Three stations with hydrographical characteristics similar to those found at OWSM were selected from leg 5 of TTONAS (Fig. 1). These data were chosen due to relatively similar hydrographical characteristics to those found at OWSM (see Fig. 5). Nitrate values lower than $0.5 \mu \mathrm{mol} \mathrm{kg}{ }^{-1}$, which were the case for a few data points, have been excluded in both datasets to avoid situations with possible overconsumption of carbon at low nutrient levels (Falck and Anderson, 2005). Table 2 provides the main outputs of the calculation. The calculated $C_{T}$ residuals $\left(C_{T \text { measured }}-C_{T \text { predicted }}\right)$ from the two datasets were relatively homogenously distributed around zero throughout the water column (Fig. 6), which support the choice of independent variables for the $C_{T}$ prediction. The highest scatter is found in the surface layer, an area of high biological activity, which suggests that the method does not fully compensate for the biology. The distribution of the $C_{T}$ residuals is used to estimate the precision of the eMLR method, which is determined to be $\pm 7 \mu \mathrm{mol}$ $\mathrm{kg}^{-1}$ in the upper $200 \mathrm{~m}$ and $\pm 4 \mu \mathrm{mol} \mathrm{kg}{ }^{-1}$ below $200 \mathrm{~m}$.

Figure 7 presents the anthropogenic increase of inorganic carbon at OWSM in the Norwegian Sea over the 24 years period from 1981 to 2005 . The variation in the surface layer is large but the overall picture is that anthropogenic carbon seems to have entered the whole water column during these 24 years. The deep layer $(2000 \mathrm{~m})$ experienced a low anthropogenic carbon increase of $9 \pm 4 \mu \mathrm{mol} \mathrm{kg}^{-1}$, and the anthropogenic carbon content of the upper water mass (200-400 m)
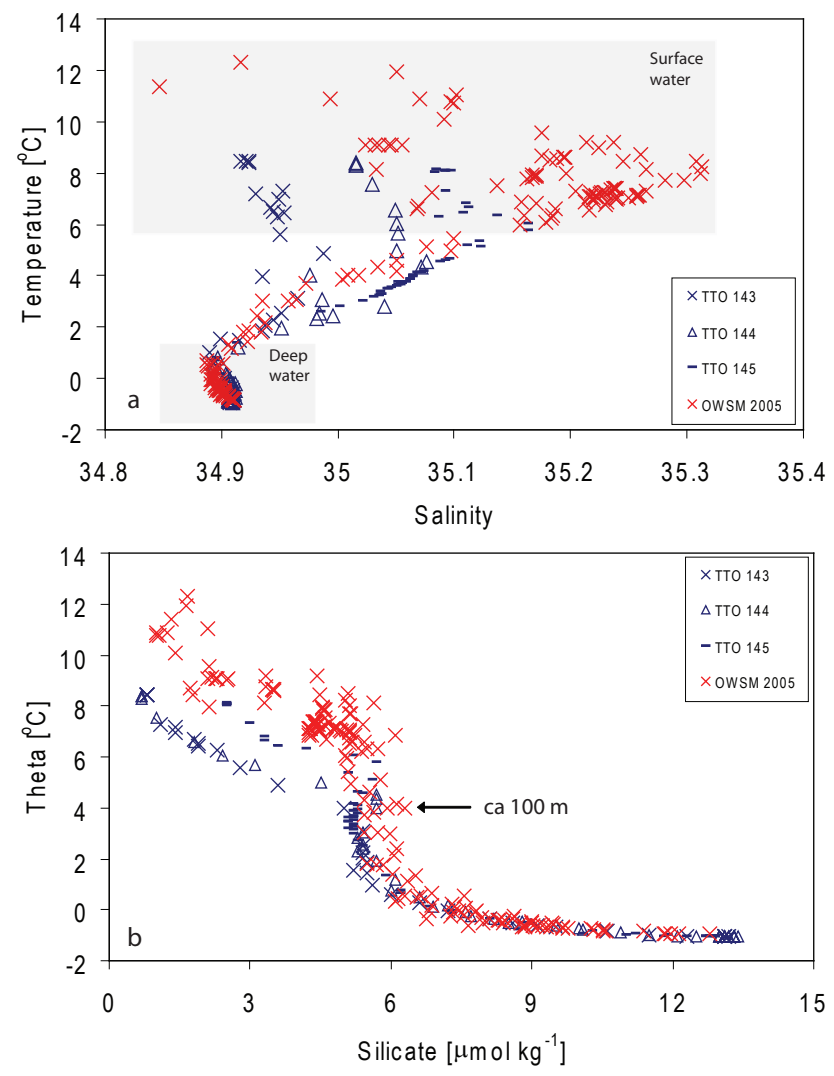

Fig. 5. (a) Temperature vs. salinity and (b) theta (potential temperature) vs. silicate, based on data from TTO-NAS stations 1981 (different blue symbols, see Fig. 1) and OWSM 2005 (red crosses).

increased by $25 \pm 7 \mu \mathrm{mol} \mathrm{kg}-1$. These values translate to annual rates of about 0.4 and $1 \mu \mathrm{mol} \mathrm{kg}^{-1} \mathrm{yr}^{-1}$, respectively at $2000 \mathrm{~m}$ and $200-400 \mathrm{~m}$.

The eMLR method was checked by using Eq. 2 to backward calculate the $\Delta \mathrm{C}_{T}^{\text {,ant }}$, i.e. regression constants for TTO data subtracted from regression constants for OWSM data and further multiplied with TTO data. This showed an anthropogenic carbon increase similar to Fig. 7, which confirms the solidity of the eMLR method.

OWSM data from 2006 were also tried out in the anthropogenic carbon change calculation, but due to unrealistic fluctuations and bias in the surface anthropogenic carbon values these data were not used further in the eMLR calculations.

The number of anthropogenic carbon estimates in this area is scarce. Olsen et al. (2006) used a similar approach for estimating anthropogenic inorganic carbon content at a location west of OWSM, and they reported increases of the surface and deep waters of about 0.8 and $0.3 \mu \mathrm{mol} \mathrm{kg}^{-1} \mathrm{yr}^{-1}$, respectively, which is slightly less than the increases reported in the present study.

Chen et al. (1990) and Anderson et al. (2000) estimated anthropogenic carbon signals for the Greenland Sea Deep 
Table 2. Parameters and coefficients of Eq. 1 for the two different datasets TTO-NAS (1981) and OWSM (2005) determined from the eMLR approach, and statistics connected to the predicted $C_{T}$.

\begin{tabular}{llllllllll}
\hline \multicolumn{1}{c}{ Salinity } & Nitrate & Silicate & $\theta$ & & & \\
\hline & $\mathrm{a}$ & $\mathrm{b}$ & $\mathrm{c}$ & $\mathrm{d}$ & $\mathrm{e}$ & $\sigma$ & $R^{2}$ & $n$ \\
TTO-NAS & -1441.67 & 101.55 & 3.31 & -0.20 & -6.65 & 4.12 & 0.99 & 85 \\
OWSM & 524.52 & 45.88 & 4.66 & -2.88 & -5.41 & 5.63 & 0.95 & 162 \\
\hline
\end{tabular}

$\theta$ is the potential temperature.

$\mathrm{a}, \mathrm{b}, \mathrm{c}, \mathrm{d}$, and e are regression coefficients specific for the particular dataset.

$\sigma, R^{2}$, and $n$ are the standard deviation, the coefficient of determination, and the number of data points used, respectively.

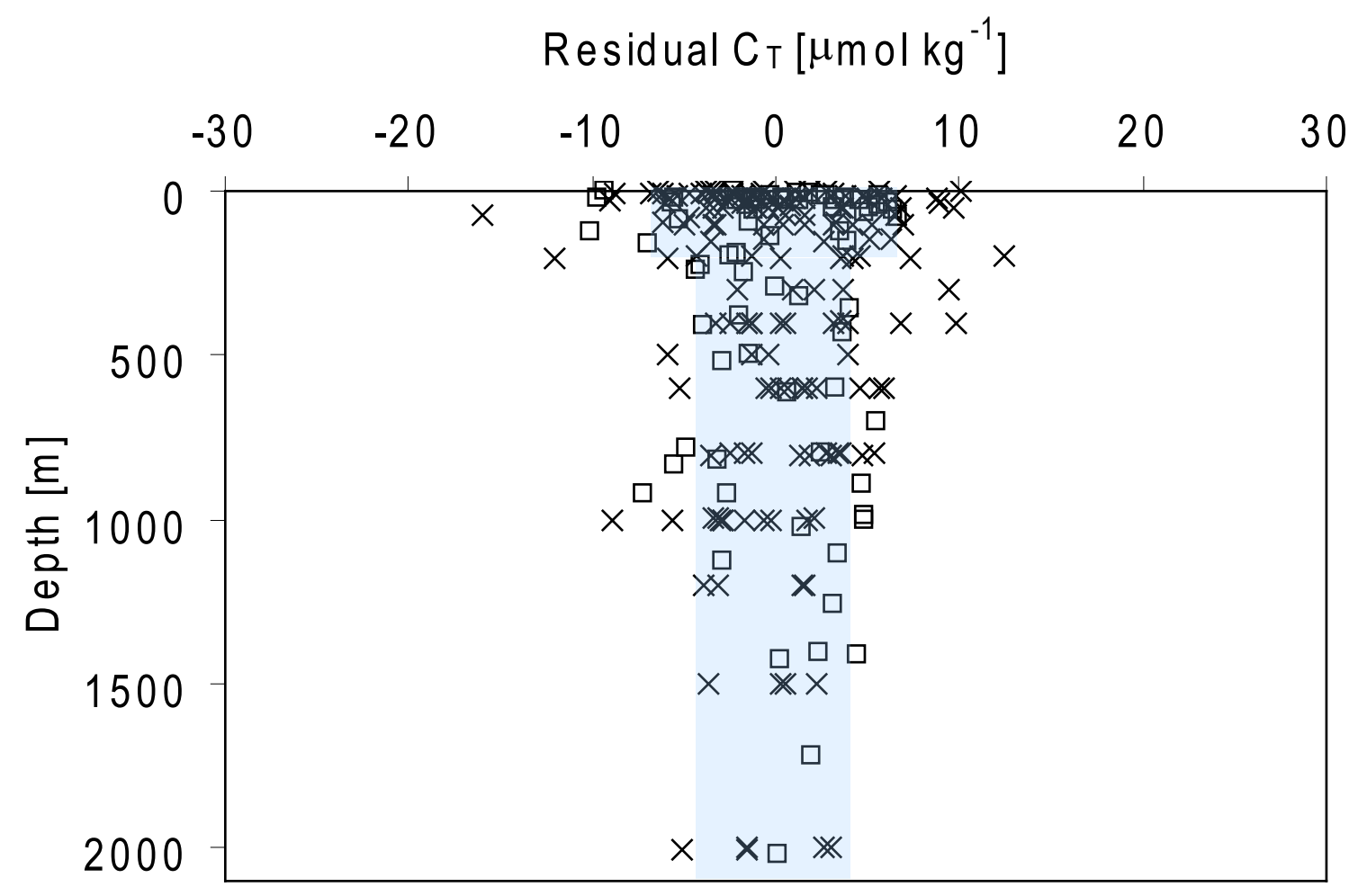

Fig. 6. Residuals of $C_{T}$ (measured minus predicted value) as a function of depth; TTO-NAS 1981 (squares) and at OWSM 2005 (crosses). The shaded area indicates the accuracy of the eMLR method of $\pm 7 \mu \mathrm{mol} \mathrm{kg}{ }^{-1}$ in the upper $200 \mathrm{~m}$ and $\pm 4 \mu \mathrm{mol} \mathrm{kg} \mathrm{kg}^{-1}$ in the deeper layers.

Water of $\sim 10 \mu \mathrm{mol} \mathrm{kg}{ }^{-1}$ in 1982 and $\sim 15 \mu \mathrm{mol} \mathrm{kg}^{-1}$ in 1994, respectively. This corresponds to an annual increase of $0.4 \mu \mathrm{mol} \mathrm{kg}-1$, which is comparable to the annual increase in anthropogenic carbon estimated for the OWSM deep water in the present study. However, it is difficult to determine any annual rate of anthropogenic change in the Greenland Sea since this depends on the strength of the deep convection which varies from year to year.

\section{Discussion}

The results show that over the years of this study the amount of inorganic carbon has increased in the entire water column at OWSM, and the increase has been largest in the surface mixed layer, and least, but still significant, in the deep water.

\subsection{Surface mixed layer}

The surface layer $(10 \mathrm{~m})$ and the mixed layer $n C_{T}$ show increases of $1.3 \pm 0.7 \mu \mathrm{mol} \mathrm{kg}{ }^{-1} \mathrm{yr}^{-1}$ and $1.2 \pm 0.9 \mu \mathrm{mol} \mathrm{kg}{ }^{-1}$ $\mathrm{yr}^{-1}$, respectively, and the eMLR estimate of anthropogenic carbon verifies the observed mixed layer inorganic carbon content. The anthropogenic increase of the mixed layer (excluding the surface water, where the method seems to be least accurate) is estimated to be about $25 \mu \mathrm{mol} \mathrm{kg} \mathrm{kg}^{-1}$ during a period of 24 years (Fig. 7), which equals an annual $C_{T}$ increase of about $1 \mu \mathrm{mol} \mathrm{kg}-1 \mathrm{yr}^{-1}$. From this it seems that 


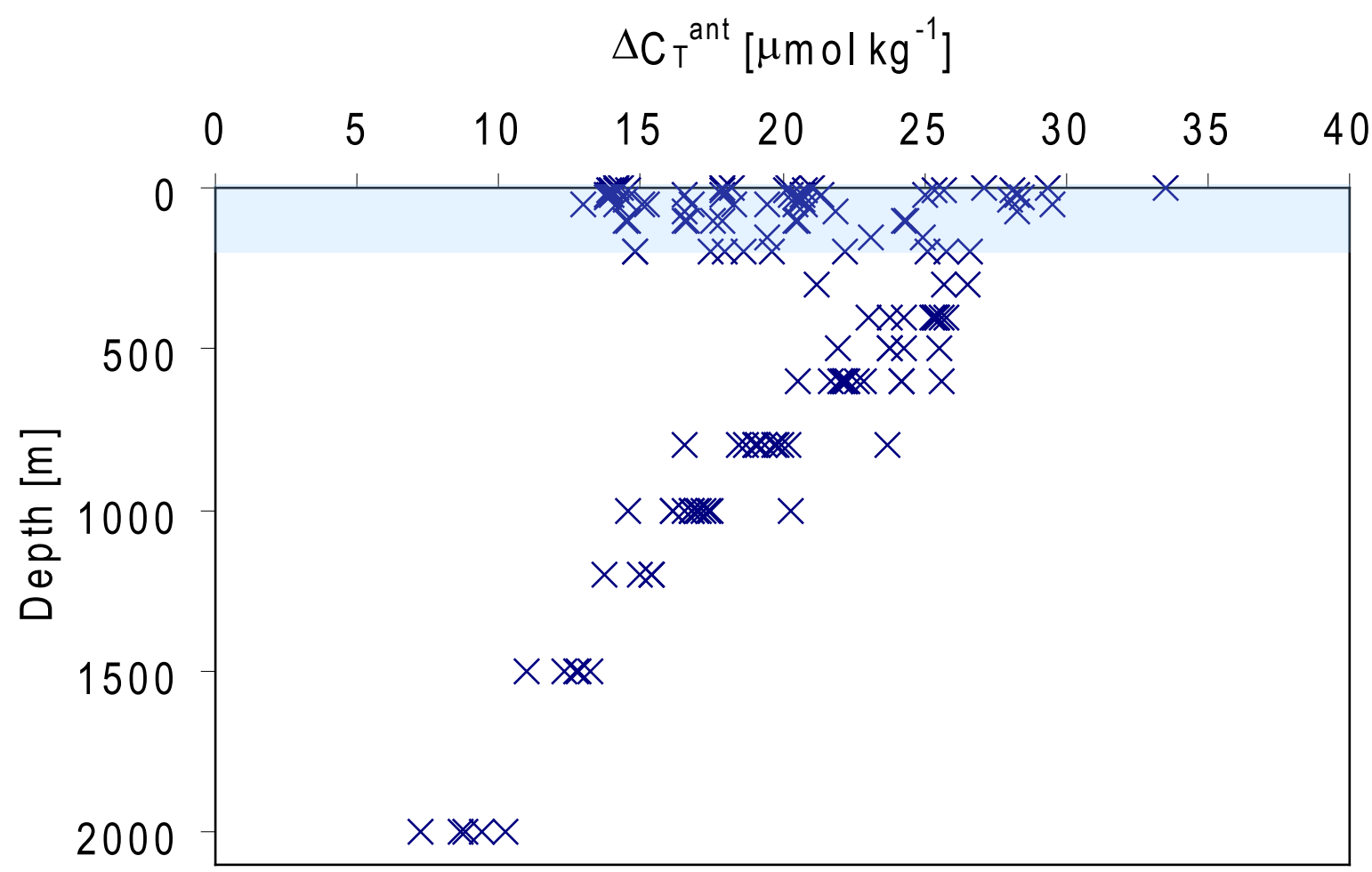

Fig. 7. Amount of anthropogenic carbon entered into the water column at OWSM from 1981 to 2005. The shaded area indicates that in the upper waters the method is less accurate than deeper in the water column.

the eMLR method, in spite of the large standard deviation, is describing the observed situation for the water in the mixed layer.

The annual surface $C_{T}$ increase corresponds to a $p \mathrm{CO}_{2}$ of $2.6 \pm 1.2 \mu \mathrm{atm} \mathrm{yr}^{-1}$ (Lewis and Wallace, 1998) which is slightly higher than the rate of atmospheric $\mathrm{CO}_{2}$ increase $\left(2.1 \pm 0.2 \mu \mathrm{atm} \mathrm{yr}^{-1}\right)$ over the years 2001 to 2006 . This is in concert with recent research (e.g. Olsen et al., 2006; Omar and Olsen, 2006) and shows that the oceanic uptake of atmospheric $\mathrm{CO}_{2}$ in this area is decreasing. The carbon content of the Atlantic Water seems to be moving towards equilibrium with respect to air-sea $\mathrm{CO}_{2}$ exchange, and may therefore in the future become a source of $\mathrm{CO}_{2}$ to the atmosphere rather than a sink. This is intuitively in contradiction to an atmosphere with an increasing amount of $\mathrm{CO}_{2}$. However, according to Wallace (2001) this can be explained by a reduced buffer capacity of the northward flowing water as a result of a reduced out-gassing at lower latitudes due to higher atmospheric $\mathrm{CO}_{2}$ levels. In this way more carbon is left in the water to be transported northwards, and when the water cools on its way towards the Nordic Seas less atmospheric carbon, compared to pre-industrial times, is absorbed in the water. This is also verified by Anderson and Olsen (2002), who showed, using a simple advective model, that lower latitudes have the largest uptake of anthropogenic $\mathrm{CO}_{2}$ from the atmosphere.

\subsection{Intermediate layer}

The largest increase in $n C_{T}\left(1.4 \mu \mathrm{mol} \mathrm{kg} \mathrm{kg}^{-1}\right)$ is observed in the intermediate layer, at $800 \mathrm{~m}$ depth. This water has its origin in the Greenland Sea and/or Iceland Sea (Blindheim and Rey, 2004), where it has received its anthropogenic carbon signature in the surface water before subduction. The observed annual increase in $C_{T}$ at this level is compared with the eMLR estimate, and the latter is about $19 \mu \mathrm{mol} \mathrm{kg}^{-1}$, or $0.8 \mu \mathrm{mol} \mathrm{kg}{ }^{-1} \mathrm{yr}^{-1}$, which then would explain nearly $60 \%$ of the observed $C_{T}$ increase.

\subsection{Deep layer}

For the OWSM deep water, an inorganic carbon increase of $0.57 \pm 0.24 \mu \mathrm{mol} \mathrm{kg}{ }^{-1} \mathrm{yr}^{-1}$ is observed based on data from 2001 to 2006. This is more than the anthropogenic $C_{T}$ increase estimated from the eMLR analysis; about $0.4 \mu \mathrm{mol}$ $\mathrm{kg}^{-1} \mathrm{yr}^{-1}$, however the numbers are small and conclusions should be drawn with care.

Part of the observed deep water inorganic carbon increase might be due to natural processes. Østerhus and Gammelsrød (1999) showed that the temperature of the Norwegian Sea Deep Water increased by about $0.1^{\circ} \mathrm{C}$ from 1987 to 1998 and during the period of this study the temperature of the deep water has increased further by about $0.004^{\circ} \mathrm{C}$ per 

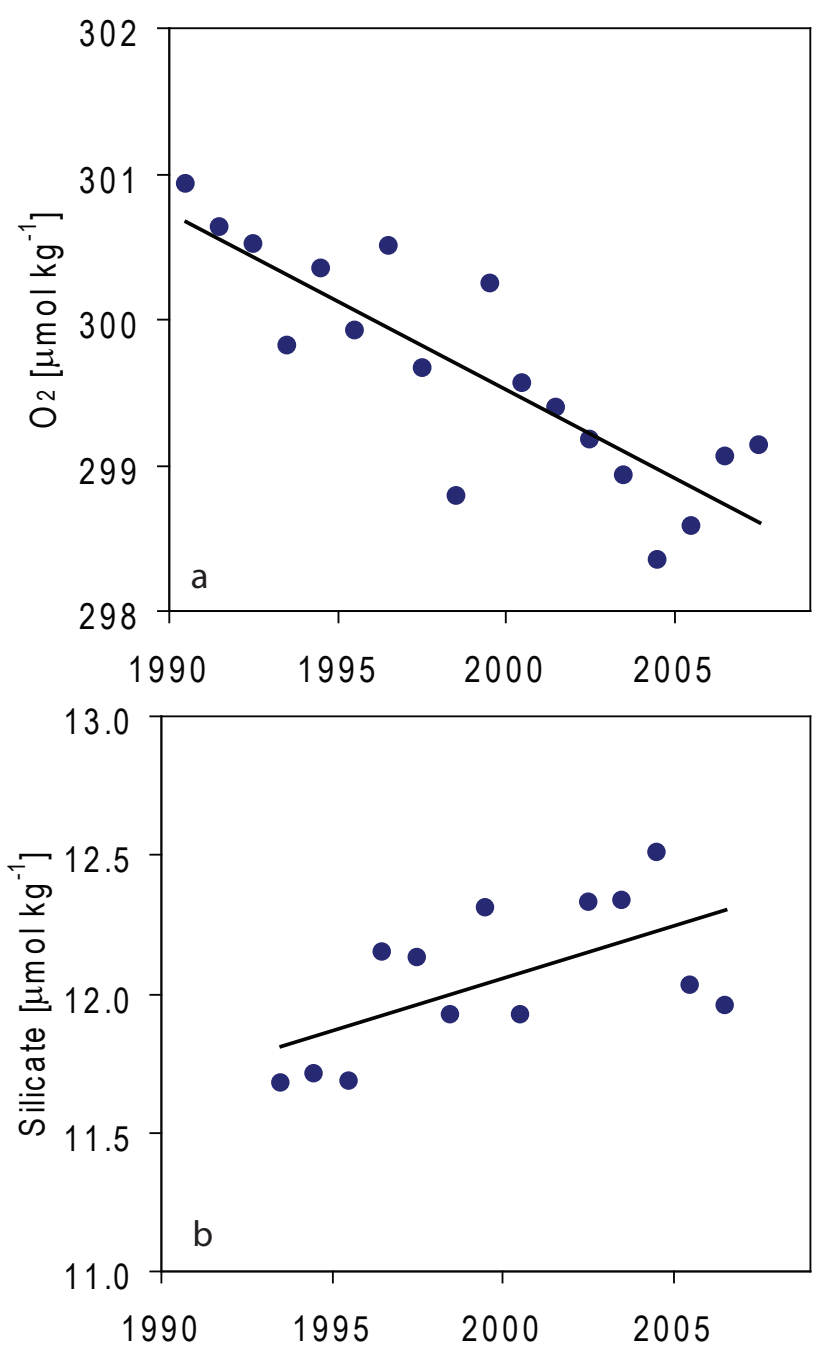

Fig. 8. Annual means of (a) dissolved oxygen and (b) silicate over the years at $2000 \mathrm{~m}$ depth at OWSM, with regression lines. Equations, number of data points, $R^{2}$, and significance level for the two regression lines are for (a) $y=-0.12 \cdot x+543,18,0.71$, and $99 \%$; and for (b) $y=0.038 \cdot x-63.2,13,0.36$, and $97 \%$.

year. This information eliminates the observed deep water $C_{T}$ increase as a temperature effect, since a similar increase in $C_{T}$ requires a decrease in temperature.

The general assumption is that the deep basin of the Norwegian Sea is fed by a mixture of deep water from the Greenland Sea, which traditionally has been colder and fresher than the deep water of the Norwegian Sea, and Arctic Ocean Deep Water, which has been warmer and saltier compared to the Greenland Sea Deep Water (e.g. Swift and Koltermann, 1988). During the 1980s the deep convection in the Greenland Sea slowed down considerably in the sense that the convection was not as deep as it previously was and only reached intermediate depths (Schlosser et al., 1991). This induced a change in the exchange between the deep basins in the Arc- tic and Nordic Seas, and a larger fraction of old Arctic Ocean Deep Water would enter the deep Greenland Sea and eventual also the deep Norwegian Sea compared to previously. This was documented by Blindheim and Rey (2004) who showed that the oxygen and silicate concentrations in the deep Greenland Sea decreased and increased, respectively, over the period from 1980s to 2000. This indicated an increased inflow of old Arctic Ocean Deep Water in which more remineralisation of organic matter had occurred. A consequence of this was also that the deep water in the Greenland Sea and Norwegian Sea warmed (Blindheim and Rey, 2004; Blindheim and Østerhus, 2005).

Figure 8 shows dissolved oxygen and silicate data from the OWSM deep water, and a similar trend as in the Greenland Sea Deep Water is seen, with the regression lines showing a decrease in oxygen of about $0.12 \mu \mathrm{mol} \mathrm{kg}^{-1} \mathrm{yr}^{-1}$ and an increase in silicate of about $0.04 \mu \mathrm{mol} \mathrm{kg} \mathrm{yr}^{-1}$. To determine the change in the deep inorganic carbon caused by the changes in water mass composition a Redfield ratio between carbon and oxygen $\left(R_{C: o}\right)$ of 106:-138 is used (Redfield et al., 1963), and the increase of carbon in the deep water due to decay of organic matter is determined to be about $0.09 \mu \mathrm{mol}$ $\mathrm{kg}^{-1} \mathrm{yr}^{-1}$. This natural process represents about $15 \%$ of the observed carbon increase of $0.57 \mu \mathrm{mol} \mathrm{kg}^{-1} \mathrm{yr}^{-1}$.

The anthropogenic part of the observed deep water $C_{T}$ increase might have several possible sources which will be discussed further. Olsen et al. (2006) estimated an anthropogenic increase in $C_{T}$ in the Greenland Sea surface water ranging between 0.6 and $0.7 \mu \mathrm{mol} \mathrm{kg}^{-1} \mathrm{yr}^{-1}$. The water convected in the Greenland Sea (down to $1500-1600 \mathrm{~m}$ in 2002; Ronski and Budéus, 2005) spreads along isopycnals and eventually enters the deep water circulation, a branch of which is the cyclonic circulation in the Norwegian Sea. It is reasonable to assume that this transport route might take about 5 years, assuming a deep current speed of $1 \mathrm{~cm}$ $\mathrm{s}^{-1}$, which is a tenth of the velocity reported by Orvik et al. (2001) for deep water at $64^{\circ} \mathrm{N} 1.5^{\circ} \mathrm{E}$. Along the way from the Greenland Sea to OWSM the water is mixed with surrounding waters and the anthropogenic signal might be diluted, but it is difficult to estimate to which extent.

The observed deep water $C_{T}$ increase at OWSM might also be explained by turning the view to the Iceland Sea. Blindheim and Rey (2004) suggest that water from the Icelandic Sea is transported further east to join the cyclonic circulation in the deep Norwegian Sea, and this is based on the observed similar characteristics of bottom waters in the Iceland Sea and the deep Norwegian Sea. According to Jónsson (1992) the strong and positive wind-stress curl during winter in the centre of the Icelandic gyre might give reason to deep convection in this area, and hereby bringing an anthropogenic carbon signal down in the water column. A fraction of this newly formed Iceland Sea Deep Water enters the south-western Norwegian Sea, joins the cyclonic gyre there, and finally reaches the OWSM deep water. 
Another source is found by addressing the recirculated Atlantic Water, which has its origin in the northward flowing Norwegian Atlantic Current where it receives its anthropogenic signal (about $1 \mu \mathrm{mol} \mathrm{kg}^{-1} \mathrm{yr}^{-1}$ to the north of the Boreas Basin surface water according to Olsen et al., 2006). It is subducted in the Fram Strait, and a fraction returns southwards into the Nordic Seas as a component of the East Greenland Current (Rudels et al., 1999). Part of this water continues into the Iceland Sea and enters the East Icelandic Current (e.g. Rudels et al., 2002). On its way the recirculated water is modified due to mixing with surrounding waters and part of it might finally enter the south-western Norwegian Sea and join the cyclonic circulation of the Norwegian Sea Deep Water. The time between the sinking of the Atlantic Water and its appearance in OWSM deep water is less than 10 years based on an effective current speed of $1 \mathrm{~cm} \mathrm{~s}^{-1}$. Therefore, an anthropogenic signal might have been transported towards OWSM via the Iceland Sea, resulting in the observed and estimated annual increase of deep water inorganic carbon.

\section{Summary}

Observations of inorganic carbon, nutrients, and hydrography at OWSM in the Norwegian Sea show that over years inorganic carbon has increased in the whole water column, and at a higher rate in the surface water compared to the deep water. This increase is verified by an extended multi linear regression method (eMLR). In the surface layer the carbon increase, converted to $p \mathrm{CO}_{2}$, is larger than the observed atmospheric increase, which is in contradiction to model results.

The observed deep water carbon increase is of both natural and anthropogenic origin and has several possible explanations; (a) remineralisation due to increased fraction of old Arctic Ocean Deep Water; (b) anthropogenic carbon input via the Greenland Sea surface water, the Iceland Sea surface water, and/or transported with the recirculated Atlantic Water. Remineralisation of organic matter represents about $15 \%$ of the deep water carbon increase observed at OWSM, but the contribution from the different pathways of the anthropogenic sources are difficult to quantify.

Acknowledgements. Financial support from the Bjerknes Centre for Climate Research (BCCR) and the Geophysical Institute, University of Bergen, are greatly appreciated. The authors are grateful to the captains and crews of $M / S$ Polarfront who kindly did all the water sampling, and to the shipping company Misje Rederi and the Norwegian Meteorological Institute, which gave us permission to use the ship. F. C. Svendsen kindly provided all the bottle salinity data. We also would like to thank our colleagues for fruitful discussions. This is publication no. A176 from the Bjerknes Centre for Climate Research.

Edited by: J.-P. Gattuso

\section{References}

Alvarez, M., Rios, A. F., and Perez, F. F.: Transports and budgets of total inorganic carbon in the subpolar and temperate North Atlantic, Global Biogeochem. Cy., 17, 1002, doi:10.1029/2002GB001881, 2003.

Anderson, L. G., Chierici, M., Fogelqvist, E., and Johannessen, T.: Flux of anthropogenic carbon into the deep Greenland Sea, J. Geophys. Res., 105(C6), 14 339-14345, 2000.

Anderson, L. G. and Olsen, A.: Air-sea flux of anthropogenic carbon dioxide in the North Atlantic, Geophys. Res. Lett., 29, 1835, doi:10.1029/2002GL014820, 2002.

Blindheim, J. and Rey, F.: Water-mass formation and distribution in the Nordic Seas during the 1990s, ICES J. Mar. Sci., 61, 846863, 2004.

Blindheim, J. and Østerhus, S.: The Nordic Seas, Main Oceanographic Features, in: The Nordic Seas - An integrated perspective, AGU Geophysical Monograph, 158, dited by: H. Drange, T. Dokken, T. Furevik, R. Gerdes, and W. Berger, 11-37, 2005.

Brewer, P. G.: Direct observation of the oceanic $\mathrm{CO}_{2}$ increase, Geophys. Res. Lett, 5, 997-1000, 1978.

Brewer, P. G., Glover, D. M., Goyet, C., and Shafer, D. K.: The pH of the North Atlantic Ocean: Improvements to the global model for sound absorption in seawater, J. Geophys. Res., 100, 87618776, 1995.

Chen, C.-T. A. and Millero, F. J.: Gradual increase of oceanic $\mathrm{CO}_{2}$, Nature, 277, 205-206, 1979.

Chen, C.-T. A., Jones, E. P. and Lin, K.: Wintertime total carbon dioxide measurements in the Norwegian and Greenland Sea, Deep Sea Res., 37, 1455-1473, 1990.

Dale, T., Rey, F., and Heimdal, B.: Seasonal development of phytoplankton at a high latitude oceanic site, Sarsia, 84, 419-435, 1999.

DOE: Handbook of methods for the analysis of the various parameters of the carbon dioxide system in sea water, ver. 2, edited by: A. G. Dickson and C. Goyet, ORNL/CDIAC-74, 1994.

Falck, E. and Anderson, L. G.: The dynamics of the carbon cycle in the surface water of the Norwegian Sea, Mar. Chem., 94, 43-53, 2005.

Friis, K., Körtzinger, A., Pätsch, J., and Wallace, D. W. R.: On the temporal increase of anthropogenic $\mathrm{CO}_{2}$ in the subpolar North Atlantic, Deep-Sea Res. Pt. I, 52, 681-698, 2005.

Gislefoss, J. S., Nydal, R., Slagstad, D., Sonninen, E., and Holmén, K.: Carbon time series in the Norwegian Sea, Deep-Sea Res. Pt. I, 45, 433-460, 1998.

Goyet, C, Coatanoan, C., Eischeid, G., Amaoka, T., Okuda, K., Healy, R., and Tsunogai, S.: Spatial variation of total $\mathrm{CO}_{2}$ and total alkalinity in the northern Indian Ocean: A novel approach for the quantification of anthropogenic $\mathrm{CO}_{2}$ in seawater, J. Mar. Res., 57, 135-163, 1999.

Gruber, N., Sarmiento, J. L., and Stocker, T. F.: An improved method for detecting anthropogenic $\mathrm{CO}_{2}$ in the oceans, Global Biogeochem. Cy., 10, 809-837, 1996.

Johnson, K. M., Wills, K. D., Butler, D. B., Johnson, W. K., and Wong, C. S.: Coulometric total carbon dioxide analysis for marine studies, Mar. Chem., 44, 167-187, 1993.

Jónsson, S.: The sources of fresh water in the Iceland Sea and the mechanisms governing its interannual variability, ICES Marine Science Symposia, 195, 62-67, 1992.

Kara, A. B., Rochford, P. A., and Hurlburt, H. E.: An optimal defini- 
tion for ocean mixed layer depth, J. Geophys. Res., 105, $16803-$ $16821,2000$.

Lewis, E. and Wallace, D. W. R.: Program Developed for $\mathrm{CO}_{2}$ System Calculations, ORNL/CDIAC-105, Carbon Dioxide Information Analysis Center, Oak Ridge National Laboratory, US Department of Energy, Oak Ridge, Tennessee, 1998.

Mosby, H.: Water, salt and heat balance of the North Polar Sea and of the Norwegian Sea, Geophysica Norvegica, 24, 289-313, 1962

Nilsen, J. E. Ø. and Falck, E.: Variations of Mixed Layer Properties in the Norwegian Sea for the period 1948-1999, Prog. Oceanogr., 70, 58-90, 2006.

Olsen, A., Omar, A. M., Bellerby, R. G. J., Johannessen, T., Ninnemann, U., Brown, K. R., Olsson, K. A., Olafsson, J., Nondal, G., Kivimäe, C., Kringstad, S., Neill, C., and Olafsdottir, S.: Magnitude and Origin of the Anthropogenic $\mathrm{CO}_{2}$ Increase and ${ }^{13} \mathrm{C}$ Suess Effect in the Nordic Seas Since 1981, Global Biogeochem. Cy., 20, GB3027, doi:10.1029/2005GB002669, 2006.

Omar, A. and Olsen, A.: Reconstructing the time history of the airsea $\mathrm{CO}_{2}$ disequilibrium and its rate of change in eastern subpolar North Atlantic, 1972-1989, Geophys. Res. Lett., 33, L04602, doi:10.1029/2005GL025425, 2006.

Orvik, K. A., Skagseth, Ø., and Mork, M.: Atlantic Inflow to the Nordic Seas: current structure and volume fluxes from moored current meters, VM-ADCP and SeaSOAR-CTD observations, 1995-99, Deep-Sea Res. Pt. I, 48, 937-957, 2001.

Redfield, A. C., Ketchum, B. H., and Richards, F. A.: The influence of organisms on the composition of seawater, in: The Sea, edited by: M. N. Hill and J. Wiley, New York, 26-77, 1963.

Rey, F.: Phytoplankton: The grass of the sea, in: The Norwegian Sea Ecosystem, ed. H.R. Skjoldal, Tapir, Trondheim, Norway, 93-132, 2004.

Ronski, S. and Budéus, G.: Time series of winter convection in the Greenland Sea, J. Geophys. Res., 110, C04015, doi:10.1029/2004JC002318, 2005.

Rudels, B., Friederich, H. J., and Quadfasel, D.: The Arctic circumpolar boundary current, Deep-Sea Res. Pt. II, 46, 1023-1062, 1999.

Rudels, B., Fahrbach, E., Meincke, J., Budéus, G., and Eriksson, P.: The East Greenland Current and its contribution to the Denmark Strait overflow, ICES J. Mar. Sci., 59, 1133-1154, 2002.

Sabine, C. L., Key, R. M., Johnson, K. M., Millero, F. J., Poisson, A., Sarmiento, J. L., Wallace, D. W. R., and Winn, C. D.: Anthropogenic $\mathrm{CO}_{2}$ inventory of the Indian Ocean, Global Biogeochem. Cy., 13, 179-198, 1999.

Schlosser, P., Bönisch, G., Rhein, M., and Bayer, R.: Reduction of Deepwater Formation in the Greenland Sea During the 1980s: Evidence from Tracer Data, Science, 251, 1054-1056, 1991.
Skjelvan, I., Olsen, A., Anderson, L. G., Bellerby, R. G. J., Falck, E., Kasajima, Y., Kivimäe, C., Omar, A., Rey, F., Olsson, K. A., Johannessen, T., and Heinze, C.: A Review of the Inorganic Carbon Cycle of the Nordic Seas and Barents Sea, in: The Nordic Seas - An integrated perspective, AGU Geophysical Monograph, 158, edited by: H. Drange, T. Dokken, T. Furevik, R. Gerdes, and W. Berger, 157-175, 2005.

Solomon, S., Qin, D., Manning, M., Alley, R. B., Berntsen, T., Bindoff, N. L., Chen, Z., Chidthaisong, A., Gregory, J. M., Hegerl, G. C., Heimann, M., Hewitson, B., Hoskins, B. J., Joos, F., Jouzel, J., Kattsov, V., Lohmann, U., Matsuno, T., Molina, M., Nicholls, N., Overpeck, J., Raga, G., Ramaswamy, V., Ren, J., Rusticucci, M. Somerville, R., Stocker, T. F., Whetton, P., Wood R. A., and Wratt, D.: Technical Summary, in: Climate Change 2007: The Physical Science Basis, Contribution of Working Group I to the Fourth Assessment Report of the Intergovernmental Panel on Climate Change, edited by: Solomon, S., Qin, D., Manning, M., Chen, Z., Marquis, M., Averyt, K. B., Tignor M., and Miller, H. L., Cambridge University Press, Cambridge, UK and New York, NY, USA, 2007.

Swift, J. H. and Koltermann, K. P.: The origin of Norwegian Sea deep-waters, J. Geophys. Res., 93, 3563-3569, 1988.

Takahashi, T., Sutherland, S. C., Sweeney, C., Poisson, A., Metzl, N., Tilbrook, B., Bates, N., Wanninkhof, R., Feely, R. A., Sabine, C., Olafsson, J., and Nojiri, Y.: Global sea-air $\mathrm{CO}_{2}$ flux based on climatological surface ocean $p \mathrm{CO}_{2}$, and seasonal biological and temperature effects, Deep-Sea Res. Pt. II, 49, 1601-1622, 2002.

Tanhua, T. and Wallace, D. W. R.: Consistency of TTO-NAS inorganic carbon data with modern measurements, Geophys. Res. Lett., 32, L14618, doi:10.1029/2005GL023248, 2005.

Tans, P. P. and Conway, T. J.: Monthly Atmospheric $\mathrm{CO}_{2}$ Mixing Ratios from the NOAA CMDL Carbon Cycle Cooperative Global Air Sampling Network, 1968-2002, in: Trends: A Compendium of Data on Global Change, Carbon Dioxide Information Analysis Center, Oak Ridge National Laboratory, US Department of Energy, Oak Ridge, Tenn., U.S.A, 2005.

Wallace, D. W. R.: Monitoring global ocean carbon inventories, OOSDP Background Report No. 5, Texas A\&M University, College Station, Texas, USA, pp. 54, 1995.

Wallace, D. W. R.: Storage and transport of excess $\mathrm{CO}_{2}$ in the oceans: The JGOFS/WOCE global $\mathrm{CO}_{2}$ Survey, in: Ocean circulation and climate: observing and modelling the global ocean, edited by: G. Siedler, J. Church, and J. Gould, 489-521, 2001.

Østerhus, S. and Gammelsrød, T.: The abyss of the Nordic Seas is warming, J. Climate, 2, 3297-3304, 1999. 